\title{
Instructional Leadership in Elementary School: An Explanatory Study
}

\author{
Wildansyah Lubis ${ }^{1}$, Rosmala Dewi, Nindy Ayu Pristanti ${ }^{1}$, Muhammad Bukhori \\ Dalimunthe $^{1^{*}}$, Gaffar Hafiz Sagala ${ }^{1}$
}

\author{
${ }^{1}$ Universitas Negeri Medan \\ *Corresponding author. Email: daliori86@unimed.ac.id
}

\begin{abstract}
This paper aims to analyze the application of instructional leadership in elementary schools. Instructional leadership analysis uses Stronge et al. [1]; Philip Hallinger [2]; Leithwood and Seashore-Louis [3] theoretical framework, which refers to four key dimensions, namely: 1) The meaning of the school's mission which is oriented to the learning program in the classroom; 2) Principal decision-making based on data and distributive leadership practices; 3) The role and commitment of the principal in the management of learning programs, and 4) The role and commitment of the principal in building a positive work climate. This study uses explanatory analysis with a qualitative approach to analyze instructional leadership in elementary schools. Data were collected using a Focus Group Discussion involving principals $(\mathrm{N}=8)$ and teachers $(\mathrm{N}=5)$ of elementary schools from Medan and Deli Serdang, Indonesia. Data analysis techniques use through stages, namely data reduction, data presentation, and concluding. The results revealed that the principal in the subject school had a policy direction aimed at learning effectiveness. However, several aspects need to be optimized, especially from organizational systems, quality control regulations, and research-based decision-making. This study recommends principals to be able to maintain their leadership orientation in learning programs, maintain good communication with teachers, be committed to developing teacher professionalism, build an effective organizational system and control system, conduct research as a basis for decision making, create a conducive organizational climate, and collaborate with stakeholders to generate competitive advantage.
\end{abstract}

\section{Keywords: Instructional Leadership, Elementary School, Education, Indonesia}

\section{INTRODUCTION}

Social, science, and technology advances impact changing more responsive learning, especially in elementary schools. Various information and communication media are widely and massively available and have potentiality in teaching and learning activities. The principal, as a leader, certainly has an effective communication strategy to direct teachers to achieve optimal performance in learning. The findings of previous studies [1-6] indicate that instructional leadership is a leadership model that has been practiced in schools in North Sumatra. These findings seem to contradict some leadership theories that suggest practicing a transformational leadership style in managing schools [7]. Transformational leadership is ideal for school principals because they can consider substantial reforms as a form of innovation in school management [8]. However, on the other hand, several other studies have found that transformational leadership cannot clearly affect teacher performance improvements which ultimately have implications for student learning outcomes [9-12]

In the cultural context, local communities naturally produce instructional characteristics in each individual, which in turn, when someone becomes a leader, he will tend to have an instructional style [5]. Interestingly, several empirical studies indicate that 
instructional leadership is, in fact, compatible with the characteristics of educational organizations $[9,12]$. However, practicing instructional leadership that can spur organizational performance is not an easy job. Unfortunately, the instructional leadership practiced in North Sumatra is still only focused on orders to carry out school routines, not on learning innovations or other academic services. In fact, for the school's success, the practice of instructional leadership cannot only be command-based which is not directly related to learning activities. Thus, school principals must have strategic thinking so that the instructions they provide are of value to the organization with a logical and empirical review of the needs, capacities, and school environment as the basis for their actions [13]. Therefore, this paper aims to analyze the application of instructional leadership in elementary schools. Instructional leadership analysis uses Stronge et al. [1]; Philip Hallinger [2]; Leithwood and Seashore-Louis [3] theoretical framework, which refers to four key dimensions, namely: 1) The meaning of the school's mission which is oriented to the learning program in the classroom; 2) Principal decision-making based on data and distributive leadership practices; 3 ) The role and commitment of the principal in the management of learning programs, and 4) The role and commitment of the principal in building a positive work climate.

This issue becomes even more interesting when the disruption of technology makes appropriate leadership styles even more important. The availability of technology opens up opportunities for more flexible leadership workspaces. The use of IT will be beneficial in developing, planning, determining learning strategies, and implementing school strategic programs $[14,15]$, which will have implications for improving the quality of academic services [16]. At the managerial level, school management information systems can help principals manage organizational and pedagogical aspects such as curriculum performance, learning activities, and student achievement [17]. This opportunity can bridge the limitations of the principal's instructional style. However, if the existing instructional style is not innovated, then the opportunity will not benefit the school's success.

\section{METHODS}

This study using the qualitative research design with an explanatory method [18]. The study was conducted on principals $(\mathrm{N}=8)$ and teachers $(\mathrm{N}=5)$ from elementary schools in Medan and Deli Serdang, North Sumatra, Indonesia. The Data was collected using Focus Group Discussion (FGD) that focus on four key dimensions, namely: 1) The meaning of the school's mission which is oriented towards learning programs in the classroom; 2) Principal decisionmaking based on data and distributive leadership practices; 3) The role and commitment of the principal in the management of learning programs, and 4) The role and commitment of the principal in building a positive work climate. The data analysis technique uses data reduction, data presentation, and concluding [19].

\section{RESULTS AND DISCUSSION}

In analyzing the data, this study reviews the opinions of the respondents obtained through FGDs with the theoretical framework of instructional leadership developed by Stronge [1]; Philip Hallinger [2]; Leithwood, and Seashore-Louis [3]. The review refers to four key dimensions, namely: 1) Meaning of School Mission which is oriented towards classroom learning programs; 2) Principal decision-making based on data and distributive leadership practices; 3 ) The role and commitment of the principal in the management of learning programs, and 4) The role and commitment of the principal in building a positive work climate.

\subsection{Results}

\subsubsection{Define the School Mission}

Overall, respondents reported that principals in their institutions designed the school's vision, mission, and goals to be oriented towards classroom learning programs. Thus, the mission and goals of the school lead directly to efforts to produce effective learning. However, some subject schools use a topdown approach in formulating the vision, mission, and goals. Meanwhile, several other subject schools have used a bottom-up approach by involving teachers in formulating the school's vision, mission, and goals. In addition, the formulation of objectives refers to government regulations and curriculum designs that the government has determined. So that even though it is oriented to classroom learning, the school's vision, mission, and goals are still subject to the direction of government policy, in this case, the Ministry of Education and Culture.

Furthermore, the results of the FGD revealed that the subject schools generally reduced the organization's vision and mission into work programs with a target time of achievement per semester. The results of the formulation of the work program are socialized to teachers and involve teachers in implementing the work program by determining the implementing coordinator and his team. The progress of the work program achievement is evaluated at regular work meetings every month. At work 
meetings at the beginning of the year and the semester, school leaders communicate organizational goals and work programs. The division of tasks is generally ordered after the socialization to implement the work program following the competencies possessed by the teacher. In addition, the school also regularly evaluates learning in the previous semester and organizes coaching for refreshment for teachers and to improve the quality of learning in the year and or semester that will run.

\subsubsection{Principal Decision Making and Distributive Leadership}

Based on the data reported by the respondents, the principal collects data every month through selfreporting by the teacher. In addition, each teacher is asked to report the results of their performance in the meeting. Several schools have also used periodic and well-documented written reporting instruments.

In terms of distribution of leadership, in normal learning conditions (face to face), the principal always distributes responsibilities to teachers according to their field of expertise. In this process, there is distributive leadership. However, during the pandemic, the distribution of leadership is constrained because cannot do several tasks remotely, and the implementation of some activities was limited due to not being able to do it online. However, both in normal conditions and in a pandemic like today, principals tend to be supportive and help find solutions when teachers face learning problems.

\subsubsection{Principal's Role and Commitment in Management of Learning Programs}

Supervision from the principal in the teacher's supervision and evaluation of learning has predominantly been carried out by the principal. However, during the current pandemic, school principals do not optimally supervise and evaluate learning. There are several obstacles in online learning during the pandemic, especially device problems and internet package costs. These technical constraints occur in various institutions, so that problems are not always found quickly and effectively. So that both school principals and teachers tend to experience difficulties due to communication mediated by this technology. Under normal circumstances, teachers receive regular monitoring and evaluation every month to support the learning process. During online learning during the pandemic, teachers and school principals create discussion groups using the Whatsapp application. So that it effectively supports communication in supervision and learning in the classroom.
In developing learning programs, principals are also assisted by vice principals regularly and actively assist teachers in developing curriculum in the field of study. In this case, the teacher feels very helped by the principal and vice-principal because they coordinate with each other in preparing the curriculum for the field of study. The principal also provides communication and discussion space during monthly meetings and training to communicate and discuss curriculum development.

The principal actively monitors student learning progress through random learning supervision and directly observes student learning activity. In teacher council meetings, the principal also monitors student development through the achievement of student learning competencies. If there are students who experience a decrease in the achievement of competence, they will discuss the corrective actions to be taken with students who have problems in learning development. The teacher's progress of student learning is reported periodically to the principal every month or at teacher council meetings.

In stimulating and supervising the learning process, the principal delegates to teachers in the field of study, counseling guidance teachers, and vice-principals to observe student learning progress. The involvement of teachers and vice-principals will provide a variety of useful information on improving the learning process, which will have an impact on improving teacher performance.

Counseling guidance teachers and vice-principals greatly helped the teachers to stimulate and supervise the learning process. If there are students who have problems in learning, the teacher in the field of study is the front line to provide assistance and direction. However, if this does not work, the counseling teacher will conduct an individual guidance program for the student. All mentoring activities carried out by the study teacher and counseling guidance teacher intensively coordinate with representatives of the academic field.

The principal openly and actively accepts complaints about the obstacles faced by teachers in learning. Assisted by representatives of the academic field, the teacher will discuss their problems in learning, and appropriate solutions are sought to resolve these obstacles-quick responses from principals and vice-principals in resolving the obstacles faced by teachers in learning. Regulations and facilities in schools provide space for teachers to get protection and assistance in solving learning problems.

The principal also helps develop the teacher professional development community through the Teacher Working Group (in Bahasa: Kelompok Kerja 
Guru-KKG). In general, the KKG formed in schools will be consolidated with KKG from other schools, thus forming a Subject Teacher Consultation (in Bahasa: Musyawarah Guru Mata Pelajaran-MGMP) located in the sub-district or city. Thus, communities at the school and sub-district or city levels play a significant role in increasing teacher professionalism. In fact, some schools provide financial incentives for teachers involved in the KKG and MGMP. Of course, this is a major contribution of the principal to the development of teacher professionalism. In addition, teachers regularly and regularly hold KKG meetings as a forum for professional development in schools. In this regard, the principal warmly welcomes the initiation of teachers actively involved in development activities in the KKG.

\subsubsection{Principal's Role and Commitment in Building a Positive Work Climate}

The data from the FGD show that the principal regularly supervises and supervises the classroom when the teacher teaches to maintain the continuity of teaching hours. In addition, in terms of organizational and quality control, school principals make rules that serve as a reference for teachers to maintain consistency in implementing learning hours as a whole.

In terms of teacher professional development, principals provide opportunities and encourage teachers to participate in relevant training and support teacher involvement in teacher working groups. this can be seen from the activeness of the principal in providing information and opening access for teachers to teacher capacity-building programs relevant to classroom learning programs. However, several subject schools reported not having a high intensity in involving teachers in teacher professional development training. Some schools also reported limited use of the budget at development posts due to the limited availability of funds. Therefore, budget items are prioritized on routine activities.

Furthermore, work expectations and high integrity in schools are not very evident from the data collected. Several schools reported the achievement of work expectations in evaluating the implementation of work programs in schools. However, the respondents have not clearly explained the specific and systematic strategies to control teacher performance and produce targeted performance achievements.

The pattern of providing incentives for teachers who excel differs from each subject school. Based on FGD data, this happens because each school has different regulatory references, budget availability, and culture. Some schools stated that teachers were given incentives in the form of praise and recognition. Several other schools provide souvenirs or financial incentives. However, some other subject schools did not even provide incentives due to the strict technical guidelines for using the budget. In addition, the budget items for incentives were difficult to allocate.

In addition, some schools reported that they provided incentives to teachers in the form of funding for teacher professionalism training programs for teacher development programs. However, similar to providing achievement incentives, some schools do not allocate incentives due to budget constraints and technical guidelines.

The principal controls the achievement of organizational goals by evaluating the implementation of learning programs and other work programs. The evaluation is carried out in regular school work meetings. In general, evaluation is carried out concerning achieving the school's vision, mission, and goals. Several respondents reported that schools conducted teacher training on an internal school scale to overcome obstacles in the implementation of assignments. Thereby developing the capacity of teachers to achieve organizational goals in schools.

\subsection{Discussion}

The virtue of Instructional leadership in educational entities is the direction of leadership aimed at the effectiveness of instructional programs [20]. This meaning is different from instructional leadership, commonly known in the private sector, interpreted as command-based leadership. Instructional leadership in education is considered appropriate and important because the key activity of educational organizations is learning activities in the classroom. Therefore, schools must change the direction of orders to maximize organizational functions to grow organizational value and, in turn, achieve the expected school goals [20]. Based on these references, the schools that are the subjects of this research have a vision, mission, and goals specifically concentrated on learning activities in the classroom. However, respondents seem not yet familiar with this conception of instructional leadership because they still have a bias in meaning with instructional leadership, which has been understood in the private sector.

Furthermore, the directions and decisions taken by the principal to achieve the goals have indeed been data-oriented through teacher reporting at work meetings every month. However, researchers have not found a systematic and documented control related to evaluating the achievement of work 
programs. So that supervision is still carried out on an activity-based basis and has not been based on documented outputs. Indeed, Murphy et al. [21] conceptualized that instructional leadership can be implemented in two ways, namely direct and indirect. Indirect implementation is carried out by developing policies and regulations that function to control teachers' teaching performance. In contrast, direct implementation is carried out by direct communication through meetings, supervision, and direct reprimands. In this case, the principal practices direct interaction with the teacher in his instructional leadership practice.

Although the policy direction focuses on one aspect, namely learning. However, implementing instructional leadership that optimizes all school resources to either directly or indirectly support learning activities is a complicated matter. From the research findings, it appears that the center of activity is located at work meetings, regular meetings at the beginning of the year, teacher coaching, distribution of responsibilities, and teacher supervision. Respondents have not discussed infrastructure, availability of literature, continuous classroom action research, research-based principal decision making, the collaborative works between schools, and strategic programs that are superior to effective learning activities. [13] stated that Instructional leadership is a complex role that depends on personal, contextual, and organizational factors. Thus, besides good interactions between teachers and principals, principals must design a complex organizational system and collaboratively become the main and support system in instructional leadership. So that the school does systematically seems to optimize learning activities in the classroom.

Finally, principals were found to have the willingness and support to communicate and help teachers solve learning problems. Several subject schools have also shown their commitment to providing access and incentives for teacher competency development and incentives for teachers who excel, although at different scales. This practice is in line with the views of Blasé and Blasé [22], which state that instructional leadership can be effective if the principal has good communication with teachers, is committed to developing teacher professionalism and fosters teacher reflection. These three aspects will be useful in producing high-quality learning, namely through developing the quality of teaching and learning, monitoring student progress, and making continuous adjustments to increase success $[23,24]$. So, in general, the subject schools have practiced instructional leadership in certain contexts, especially in the direction of the principal's policy aimed at learning effectiveness. However, several aspects need to be optimized, especially from the organizational aspect and the leadership system.

\section{CONCLUSION}

This study aims to explore the application of instructional leadership in elementary schools in the digital era. In general, the study results revealed that the principal in the subject school had a policy direction aimed at learning effectiveness. Besides, the leadership attitude practiced by the subject principal also fulfills the four dimensions of instructional leadership in certain indicators. However, several aspects need to be optimized, especially from organizational systems, quality control regulations, and research-based decision-making.

Based on the results of this study and the instructional leadership literature, good communication skills, resolve conflicts, create trust to develop human resources, and produce good school quality management are important aspects for successful instructional leadership [15-17, 20]. -24]. Therefore, this study recommends principals to be able to maintain their leadership orientation in learning programs, maintain good communication with teachers, be committed to developing teacher professionalism, build an effective organizational system and control system, conduct research as a basis for decision making, create a conducive organizational climate. And collaborate with stakeholders in generating a shared competitive advantage. Further research can explore more in the practice of instructional leadership in North Sumatra with in-depth interviews or ideographic studies.

\section{ACKNOWLEDGMENTS}

The authors researched with funding from Universitas Negeri Medan through a fundamental research grant scheme in 2021. So we are grateful for the research funding that has been provided.

\section{REFERENCES}

[1] Stronge, J. H., Richard, H. B., \& Catano, N. Qualities of effective principals. Association for Supervision and Curriculum Development. 2008

[2] Hallinger, Philip. Developing instructional leadership. In: Developing successful leadership. Springer, Dordrecht, 2010. pp. 6176.

[3] Leithwood, Kenneth; Seashore-Louis, Karen. Linking leadership to student learning. John Wiley \& Sons, 2011.

[4] Sagala S, Lubis W, Sagala GH. Canonical correlation between principal leadership and 
school capacity. Int J Manag Educ [Internet]. 13(3): 2019, pp 256. Available from: http://www.inderscience.com/link.php?id=1004 13

[5] Lubis W, Sagala S, Saragih AH, Sagala GH. The Potentiality of Principal Leadership Implementation In North Sumatera. In: Proceedings of the 3rd Annual International Seminar on Transformative Education and Educational Leadership (AISTEEL 2018) [Internet]. Paris, France: Atlantis Press; 2018. Available from: https://www.atlantispress.com/article/55909196

[6] Lubis W, Sagala GH. The Impact of Principal Leadership Dimensions on School Capacity. In: Proceedings of the International Conference on Educational Sciences and Teacher Profession (ICETeP 2018) [Internet]. Paris, France: Atlantis Press; 2019. Available from: https://www.atlantispress.com/article/55915502

[7] Dewi R. Kinerja Kepala Sekolah: Pengaruh Kepemimpinan Transformasional, Konflik Dan Efikasi Diri. J Ilmu Pendidik. 18(8): 2012, pp $150-6$.

[8] Leithwood K, Jantzi D. Transformational school leadership for large-scale reform: Effects on students, teachers, and their classroom practices. Sch Eff Sch Improv. 17(2): 2006, pp 201-27.

[9] Robinson VMJ. From Instructional Leadership to Leadership Capabilities: Empirical Findings and Methodological Challenges. Leadersh Policy Sch [Internet]. Feb 24;9(1): 2010, pp 1$26 . \quad$ Available from: http://www.tandfonline.com/doi/abs/10.1080/15 700760903026748

[10] Goldring E, Porter A, Murphy J, Elliott SN, Cravens X. Assessing Learning-Centered Leadership: Connections to Research, Professional Standards, and Current Practices. Leadersh Policy Sch [Internet]. Jan 23;8(1): 2009, pp 1-36. Available from: http://www.tandfonline.com/doi/abs/10.1080/ 15700760802014951

[11] Marks HM, Printy SM. Principal Leadership and School Performance: An Integration of Transformational and Instructional Leadership. Educ Adm Q [Internet]. Aug 29;39(3): 2003, pp 370-97. Available from: http://journals.sagepub.com/doi/10.1177/0013 $161 \mathrm{X} 03253412$

[12] HALLINGER P. Leading Educational Change: reflections on the practice of instructional and transformational leadership.
Cambridge J Educ [Internet]. Nov 3;33(3): 2003, pp 329-52. Available from: http://www.tandfonline.com/doi/full/10.1080/ 0305764032000122005

[13] Hallinger P, McCary CE. Developing the Strategic Thinking of Instructional Leaders. Elem Sch J. 91(2): 1990, pp 89-108.

[14] Ainley J, Kos J, Nicholas M. Participation in science, mathematics and technology in Australian education. Aust Counc Educ Res Monogr [Internet]. (63): 2008, pp 86. Available from: http://research.acer.edu.au/acer_monographs/

[15] Balanskat A, Gertsch C. Balanskat, A., and C. Gertsch. "Digital skills working Group: Review of National Curricula and Assessing Digital Competence for students and teachers. European School net, Brussels; 2010.

[16] Vanderlinde R, van Braak J, Dexter S. ICT policy planning in a context of curriculum reform: Disentanglement of ICT policy domains and artifacts. Comput Educ [Internet]. May; 58(4):2012, pp 1339-50. Available from: https://linkinghub.elsevier.com/retrieve/pii/S0 36013151100323X

[17] Blau I, Presser O. e-Leadership of school principals: Increasing school effectiveness by a school data management system. Br J Educ Technol [Internet]. Nov; 44(6): 2013, pp 1000-11. Available from: http://doi.wiley.com/10.1111/bjet.12088

[18] Creswell, J. W. (2014) Research Design: Quantitative, Qualitative, and Mixed Method ( $4^{\text {th }}$ ed). Thousand Oaks, CA: Sage

[19] Huberman, M., \& Miles, M. B., The Qualitative Reseacher's Companion. Sage, 2002.

[20] Horng E, Loeb S. New Thinking about Instructional Leadership. Phi Delta Kappan [Internet]. Nov; 92(3): 2010, pp 66-9. Available from: http://journals.sagepub.com/doi/10.1177/0031 72171009200319

[21] Murphy JF, Weil M, Hallinger P, Mitman A. Academic Press: Translating High Expectations into School Policies and Classroom Practices. Anal Chem. 42(13): 1970, pp 108A-108A.

[22] Blase J, Blase J. Handbook of instructional leadership: How really good principals promote teaching and learning. Thousand Oaks: CA: Corwin Press; 1998. 
[23] Al-Mahdy YFH, Emam MM, Hallinger P. Assessing the contribution of principal instructional leadership and collective teacher efficacy to teacher commitment in Oman. Teach Teach Educ [Internet]. Jan;69: 2018, pp 191-201. Available from: https://linkinghub.elsevier.com/retrieve/pii/S0 $742051 X 17308752$

[24] Lubis, Wildansyah, et al. Measuring valuable antecedents of instructional leadership in educational organisations. International Journal of Management in Education, 15.1: 2021, pp 41-57. 